\title{
Export between the Poles Globalisation and Regionalisation-using the Case of the Austrian District Burgenland
}

\author{
Doris Maria Granabetter \\ University of Applied Sciences Burgenland (UAS), Eisenstadt, Austria \\ University of Sopron, Hungary
}

Correspondence should be addressed to: Doris Maria Granabetter; doris.granabetter@wkbgld.at

Received date: 28 August 2015; Accepted date: 9 December 2015 ; Published date: 8 February 2016

Academic Editor: Rozalia Kicsi

Copyright (C) 2016. Doris Maria Granabetter. Distributed under Creative Commons CC-BY 4.0

\begin{abstract}
Burgenland is located in the eastern part of Austria. 17.000 companies of the sectors: business, industry and trade are members of the Economic Chamber. Nearly $5 \%$ of them are engaged in exports, as compared to the Austrian average, $10 \%$ of the entrepreneurs are engaged in operations abroad. The region was defined as an Objective 1-area from 1995 to 2006. Burgenland took benefit from the Phasing-Out Programme from the years 2007 to 2013. According to the Regional Management Burgenland (2014), the area will be a region in transition from 2014 to 2020 . The development plan focused and still focuses on research, innovation, strengthening the competitiveness of small and medium-sized enterprises and supports investments in energy efficiency in Burgenland. This paper focuses on the expectations of entrepreneurs in Burgenland using an online questionnaire and an expert interview. The aim is to provide more information about the propensity to start businesses on foreign markets and the conditions which need to be fulfilled by the economy to export successfully. Burgenland's entrepreneurs currently see chances in foreign markets. Their initial position is better than ever - especially when it comes to infrastructure, funding and the support to enter the market. The trend to globalisation or regionalisation is dependent on the local structure of the economy and the demand on the home market. In different sectors and in different areas of the world globalisation and regionalisation supersede each other and coexist depending on the political, economic and environmental situation.
\end{abstract}

Keywords: Burgenland, export tendency, globalisation, regionalisation

\section{Introduction}

Burgenland, the eastern district of Austria, was determined by the European Union to be Objective 1 area from 1995 to 2006.833 million euros were invested in this period of time. From 2007 to 2013, Burgenland received financial aid of 444 million euros from the Phasing-Out Programme. The area is said to be a region in transition from 2014 to 2020. 72,3 million euros are currently in the European Social Fund (ESF) and the European Regional Development Fund (EFRE) providing 
money for research, innovation, strengthening the competitiveness of SMEs and investments in energy efficiency in Burgenland. According the Regional Management of Burgenland, the region generated $64 \%$ of the gross domestic product (GDP) on the EU average in the year 1994. Today, after several aid programmes, the Burgenland reaches $82 \%$ on the EU average. From 1994 till now the export rate doubled.

Goods "made in Burgenland"are enjoying great popularity abroad. The export numbers of the producing companies increased to a record level of 1,3 billion euros (without merchandise revenues) in 2014. The electronic industry has the highest export rate with $86,2 \%$, followed by the chemical industry with $84,9 \%$. Three of four business partners have their head office in the euro zone. Nevertheless, Burgenland's producing enterprises are the taillight in the ranking of the Austrian districts with an export rate of 35,8\%. Every six months the Economic Chamber of Austria collects data about the economic expectations of the entrepreneurs of the country. The final study is called "Wirtschaftsbarometer" (2015) and is being published by the Economic Chamber and Statistic Austria. It shows that the entrepreneurs of Burgenland await a new record in export sales.

Summed up:

- Burgenland has the lowest rate of exports of all Austrian districts.

- Although the export rate has doubled in the last two decades.

- The expectations of Burgenland's entrepreneurs, concerning export sales, are prognosed to reach a record level compared to other Austrian

districts.

\section{Foundation of research work}

"Globalisation"and "regionalisation"are terms used by many but defined by few (Oman, 1996). Globalisation is not a new process. Oman (p5) defines three distinct periods or "waves"of globalisation in the last 100 years. The first wave took place about 50 years before World War I, the second one during the 1950s and 1960s, and the current one started around the 1980s. Nowadays globalisation is a specialised and difficult process, especially on the microeconomic level.

Oman continues saying that regionalisation can be a phenomenon, driven by political forces, or it can be an outcome of the same microeconomic forces that rule globalisation. Regionalisation does not always happen in the form of an arrangement among governments. It is not always a political phenomenon. It can also be "natural".

How to define a region? In the literature it is differentiated between it is spoken about regionalism and regionalisation. Internationally meaning - regionalism is the expression of a common sense of identity of nations combined with the implementation of institutions. Those institutions express a particular identity and shape collective actions within a geographical region. A key feature of the new regionalism, according to Breslin, is the significance of multiple coexisting forms of regions. Regionalism is both - a quantitative and qualitative - important factor in global politics (Breslin/Hughes/Philips/ Rosamond, p 18).

Regionalisation indicates smaller segments - the so-called regions. One of the most obvious examples of regionalisation is the division of a nation into states or provinces, like dividing Austria in 9 districts (Vienna, Tyrol, Styria, Burgenland etc.).

This study focuses on both terms: Globalisation and regionalisation. Economists tend to say the chances of globalisation happening are better, when the possibilities for efficiency increase. They are able to see the forces that help channelling the energy of people and resources of countries. The main goal is being as productive as possible. Oppositional globalisation means transporting over long distances, pollution, great willingness of flexibility and highenergy costs.

Do entrepreneurs prefer to sell their goods locally or internationally? Their 
preferences are being researched in this study through

- $\quad$ an online survey and

- the analysis of secondary data and

- an expert interview with the Austrian trade representative in Ireland.

The objects of the research are the exporters and non-exporters of Burgenland/Austria. According to WKO statistics (2015) the Burgenland Economic Chamber has 17.321 members. Approximately $5 \%$ of them have been engaged in exports. In comparison: $10 \%$ of all Austrian entrepreneurs were in engaged in exports. The economy in Burgenland is very small structured. Compared to other Austrian regions, like Upper-Austria or Vienna, Burgenland has only a few industrial companies and three out of four companies do not employ any staff. Burgenland as an Objective 1-area is a prototype for other regions.

Web surveys have emerged to be the most popular method for collecting primary data of markets and social structures. According to Keusch (2015), "Web surveys are a costand time efficient alternative"(p. 2). They are incredibly useful in gathering information from a specific group of people.

As compared to offline-surveys, onlinesurveys' data-quality is regarded to be better, conditioned by honest answers, less effects of social desirability and highly felt anonymity. Disadvantages are the unclear identity of the sample of the survey and possible technical difficulties (Thielsch and Weltzing, p 110).

The survey focuses on:

- The expected chances in foreign markets

- Opinions about important factors for exporting

- Awareness of the different services, information and consulting offers
- Sources of information about export topics

- Possible new markets to export or invest

- Estimation of realistic export share in 5 and 10 years

- Estimation of chances and risks for exporters in general

- Rating of 10 different statements about the importance of export

Besides this array of questions the respondents had to declare their business sector and the region, where the company is located. Question 11 was the chance to express one's view to the topic. 10 of 12 questions were compulsory. The questionnaire's results form the base of the expert interview.

\section{Realisation: online survey, expert interview and secondary data}

The online survey uses different channels of communication. The questionnaire has been uploaded to the platform, www.umfrageonline.de. The representator of businesses interests, the Economic Chamber, has its own website, which you can find under the following address http://wko.at/bgld. They also offer a weekly newsletter. At stage three of the survey a link to the questionnaire was sent embedded in a personal e-mail. 998 entrepreneurs, who were in touch with the topic during the last couple of years, received an e-mail. They had a question concerning export, they visited exportrelated meetings or they had contact with the export department in the Economic Chamber. 42 entrepreneurs responded to all of the questions of the survey.

According to the analysis, it must be mentioned that 7 out of the 42 entrepreneurs $(16,7 \%)$ are not yet engaged in exports, the other $35(81,4 \%)$ already succeeded on foreign markets.

$5 \%$ of 17.321 entrepreneurs in Burgenland are already active in export, which means in numbers 866 members of Burgenland's Economic chamber. If you have a look at the different branches, maximally 11.000 
companies could export or invest in foreign countries. On the other hand, only about 6.000 companies got offers on the local market.

The answers of the online survey were linked to an expert interview with Wilhelm Nest, who is the Trade Commissioner of the Austrian economy in Dublin/Ireland.

The base of the analysis is secondary data provided by the Economic Chamber of Austria and Statistic Austria. The 'Wirtschaftsbarometer 2015' was especially useful.

\section{Study results}

$35(81,4 \%)$ of the 42 respondents of the online survey are already engaged in exports. At the moment only $7(16,7 \%)$ of them limit their business acitivities to the home market. They were asked questions about the expected chances and risks, their attitude, the preferred channels of communication and the target markets.

The top destinations for most of the respondents are Germany (27 namings), followed by Netherlands (19), then Hungary and Belgium (16).

Testimonials are no actuator for going abroad (2,71). Information about new markets $(1,529)$ and the support to enter the market $(1,57)$ are seen as very important. The evaluation followed the scale from 1 (very important) to 5 (unimportant).

The Austrian Trade Division of the Austrian (AWO) Economic Chamber is well known (25 namings). The respondents are familiar with its export newsletter (22) and the advisory package of the AWO (21). The awareness that comes along with the export newsletter is confirmed by the answers to the question about information sources $(2,57)$. The evalution followed the scale from 1 (very important) to 5 (unimportant).

The respondents are very optimistic about their chances in the future. Only 3 think that their market share in foreign markets will decrease over the next 10 years. On a scale from 0 (more risk) to 100 (more chance) the arithmetic average is 63,14 .
The standard deviation is 23,98, the average absolute deviation 19,62.

The respondents declare their opinion with confidence in Austrian products, their image around the world (34 namings) and the potential in increasing the volume of exports (32). Self-critically they mark the need of Burgenland's economy to export (25).

The majority of the interviewees belong to the division of trade (24 namings) and are located in the region of Neusiedl/See, which is in the north of Burgenland.

The questions form the base of the expert interview with Wilhelm Nest. He is the representative of the Austrian Economic Chamber in Ireland. His responsibilities are charging the chances of Austrian businesses on the Irish market, helping to enter the market and organising exhibitions, trade fairs and business meetings.

According to him, Burgenland's economy has good chances in the sections food, beverage (especially wine), construction and energy. Ireland has no natural resources and is an ideal market for alternative energy. Ireland already imports a small amount of wine, equipment for solar energy, traffic lights and intelligent traffic systems.

He thinks the first step to get a foreign business partner is visiting one of the events of the Economic Chamber in the home country. There are a lot of interesting markets besides big players like China or the US. He also suggests that the first sales market abroad should be one of the neighbour markets, because of the high costs, that could be developed to initiate business contact.

\section{Results discussion}

The accounting balance of the survey "Wirtschaftsbarometer" for the first half of 2015 showed optimism concerning exports. 156 entrepreneurs who have their company in Burgenland participated. But what motivates them to see a positive future? The analysis of the secondary data gives no insight in the motivation of the respondents. 
The results of the online survey underpin the positive view. On a scale from 0 to 100 , the arithmetic mean is 63,14. The respondents tend to see more chances, than risks in export. They are not afraid of competing globally. The answers show the self-confidence of the entrepreneurs and their offers. $81 \%$ of the respondents say that Austrian products have a good reputation abroad. Export is a good backbone for the Austrian economy (78,6 $\%$ ). They do not trust domestic consumption. Only $42,9 \%$ of the respondents think that Austria is an economy-friendly environment. On the other hand, more and more marketing activities focus on the local market. The Economic Chamber of Burgenland launched a local campaign with the title "Look at Burgenland". The district of Tyrol, which is located in the western part of Austria, does the same for its area. After the embargo in Russia the local products are forced into local restaurants and shops. Consumers are told to buy local produced goods and services, but in times of increasing numbers of online shopping Could this trend really survive?

A focus group of entrepreneurs will try to ensure that the results are accurate and figure out more facts about the motivation behind staying on the home market or going abroad. An important group are the consumers. What do they prefer? What goods are bought close to the consumer? What is ordered on the World Wide Web? The study must be enlarged to clarify the intensions of the consumers.

\section{Summary}

The businesses in Burgenland see great chances on foreign markets. They want to compete globally. On the other hand, they are selling locally. A great fact is the sector and the size of the company. Especially the industry is dependent on foreign markets. The economy in Burgenland is very small structured at the moment. A modification of the regional economy could make Burgenland more competitive on foreign markets.

The EU-Funding programmes were a first step to stimulate the economy in the Objective 1-area Burgenland, but the local government has to carry on the trend after
2020 , which will be the end of the funding period.

With the Division Advantage Austria and the Austrian Economic Chamber businesses have a great network with more than 110 offices all around the globe. From small companies, even one-personbusinesses, to great industry companies every entrepreneur can benefit from the offers, showcases, exhibitions and market exploration trips. The ministry of economics and the Economic Chamber of Austria provide 56 million euros to support Austrian businesses till 2019.

The Austrian Minister for Economic Affairs and the President of the Austrian Economic Chamber want to gain 8.000 new exporters within the next four years (APA, 2015).

The entrepreneurs in Burgenland see their chances abroad, but the satisfying sales figures on the home market lead them to stay safe on the home market. Wilhelm Nest, the Austrian Trade Commissioner in Ireland, summed up: "When businesses are engaged with the domestic demand, they have no intension to go to another, foreign market".

The trend towards globalisation and regionalisation depends on the local structure of the economy and the demand of the home market. In different sectors and in different areas of the world, globalisation and regionalisation will come and go in waves, depending on the political, economic and environmental situation. The key issue is: Will we have the resources to act globally?

\section{References}

1. APA (2015), Exportoffensive "go international" wird bis 2019 verlängert. [Online], [Retrieved August, 4, 2015], http://www.aomweb.apa.at.

2. Breslin, S., Higgot, R., Philips. N. and Rosamond, B. (2003), New Regionalism in the global political economy. Theory and cases,

18.

3. Keusch, F., (2015), Why do people participate in Web surveys? Applying a survey participation theory to Internet survey data collection. [Online], [Retrieved 
March 9, 2015], http://link.springer.com/article/10.1007/ s11301-014-0111-y\#page-1.

4. Oman, C. (1996), The Policy Challenges of Globalisation and Regionalisation, OECD Development Centre Policy Briefs, No. 11, OECD Publishing Paris.

5. Regional Management Burgenland (2014), "Startschuss für Burgenland 2020." [Online], [Retrieved August 25, 2015], http://www.phasingout.at/de/aktuelles/1948.

6. Statistic Austria (2015), Außenhandel nach Bundesländern. [Online], [Retrieved March 9,

2015] http://www.statistik.at/web_de/statistike n/aussenhandel/regionaldaten_nach _bundeslaendern/index.html.

7. Thielsch, M.T., and Weltzing S., (2012), Online-Umfragen und OnlineMitarbeiterbefragungen, Praxis der Wirtschaftspsychologie II: Themen und
Fallbeispiele für Studium und Praxis. Münster, Germany: MV Wissenschaft, 110.

8. WKO Statistics, (2015), Exporte weiter auf Erfolgskurs, Wirtschaftskammer Österreich. [Online], [Retrieved August 25, 2015],

https://www.wko.at/Content.Node/iv/Exp orte-Gewerbe-Industrie-2015.html.

9. WKO Statistics, (2015), Jahrbuch Kammermitglieder nach Bundesländern, Wirtschaftskammer Österreich. [Online], [Retrieved March 9, 2015], http://wko.at/statistik/jahrbuch/mg-

km.pdf.

10. WKO Statistics, (2015), WKÖWirtschaftsbarometer Frühjahr 2015 Burgenland, Wirtschaftskammer Österreich. [Online], [Retrieved August 30, 2015],

https://www.wko.at/Content.Node/kampa gnen/ wirtschaftsbarometer/ Wirtschaftsbarometer-Fruehjahr2015.html. 